\title{
Physical Education and Character Education
}

\author{
Helmy Firmansyah \\ Faculty of Sport and Health Education \\ Indonesian University of Education \\ Bandung, Indonesia \\ helmy.firmansyah@upi.edu
}

\begin{abstract}
The main objective of physical education teaching is the overall personality development, such as physical, mental, emotional, social and spiritual aspects. These aspects systematically, through the participation of physical activity was based on the health and social norms (values, behavior, fair play). The method used in this research is descriptive method with survey techniques. The population is as much as 351 students. The results is $\mathrm{PE}$ can increase problem solving ability, stimulate the development of language and verbal skills, develop social skills, and a container of emotional expression, teach children to recognize and respect other people.
\end{abstract}

Keyword-physical, education, character

\section{INTRODUCTION}

In sport and physical activity can be established the positive traits of personality and social responsibility. [1] Thus, with the right strategy it is in line with the six pillars of character; trust, respect, responsibility, fairness, caring and good citizenship. [2] However, these character, sportsmanship and disciplines in sports cannot positively influence character development especially if 'winning' being emphasized. [3] Perhaps, the 'winning emphasize' implants for coaches and athletes by the administrators will invite inappropriate behavior like cheating, overly aggressive or taking drugs for better performances. [4]

Character education describes curriculum developed to teach children about essential traits needed to build good character. It is a deliberate effort to develop noble character and cultivate core virtues that are worthy for the individual and society as a whole. It requires careful, calculated planning for success. [5] It deals with teaching students to develop the ability to decide how to behave in an appropriate manner in various social situations with the purpose of developing individuals who are capable of understanding moral values and who choose to do the right thing.

[6] defined character education as any overt or conscious attempt to effect the development of desirable individual traits or qualities. The value of cooperation can also be done. Physical education through cooperation with habituation team / group on sports games. The success of a team sports is determined by the cooperation of each team member. Attitude of cooperation in this sports game expected to be implicated in the life society in a broader field.

The material in the form of games and physical education and sports terms with binding regulations. Habituation obey the rules in the game and this exercise is expected to be implicated in other areas of life more broadly. Obedience of the rules is one indication discipline and responsibility. To instill this value through physical education can be done with some the action of which is to familiarize participants students help teachers prepare learning tools, instill a sense of empathy to a friend or foe play when it suffered an accident, visit a sick friend, to raise funds through the social event sport, exercise with sportsmanship, and a friendly match. Sensibility social on the sports field is expected to implemented in public life so bring a shared affection, mutual help, and empathy for the suffering other people.

Although a number of definitions and interpretations of character education are found in the literature, the content of programs typically align with the core principles and values of generosity, kindness, honesty, tolerance, trust, integrity, loyalty, fairness, freedom, equality, and respect of and for diversity. [7] Experts in the field of character development recommend implementing a character education curriculum in the elementary and middle school years which includes the aforementioned traits to help students become responsible, respectful, contributing members of our democratic society.

The value of cooperation can also be done in physical education through cooperation with habituation team / group on sports games. The success of a team sports is determined by the cooperation of each team member. Attitude of cooperation in this sports game expected to be implicated in the life society in a broader field. The material in the form of games and physical education and sports terms with binding regulations.

Habituation obey the rules in the game and this exercise is expected to be implicated in other areas of life more broadly. Obedience of the rules is one indication discipline and responsibility. To instill this value through physical education can be done with some the action of which is to familiarize participants students help teachers prepare learning tools, instill a sense of empathy to a friend or foe play when it suffered an accident, visit a sick friend, to raise funds through the social event sport, exercise with sportsmanship, and a friendly match. Sensibility social on the sports field is expected to implemented in public life so bring a shared affection, mutual help, and empathy for the suffering other people.

Character traits such as morality, self esteem, self efficacy and resilience have been associated with desirable life 
outcomes, including lower levels of stress, experiencing positive growth after stressful periods, fewer alcohol and drug related problems, Academic achievement, being willing to set challenging life goals, and pro social behavior. [8] It is natural therefore that attempts are made to promote these positive character qualities in young people. While well-structured and implemented programs and interventions may positively influence elements of character, research in the area of physical education and character development remains scarce.

Physical fitness involves physical, organic freshness and freshness motor. Physical concerns the proportions of the body, the relationship between bone, fat, muscle, height and weight. While organic freshness include equipment efficiency increase of the body such as the heart, lungs, liver, kidneys and so on. Agility, strength, balance and flexibility associated with motor freshness someone. [9] detailing the purpose of physical education as follows: (1) development of the individual, concerning the efficiency of physiological and physical balance; (2) address the environment that emphasizes the spisial orientation and manipulation of objects; and, (3) social interaction that includes: communication, interaction between groups and cultures.

\section{RESEARCH METHOD}

The approach used in this study is a qualitative approach, in which this approach is a research procedure that produces descriptive data with observed behavior, an approach that describe or examine more deeply a situation exists in the field with a view to know the character building of students.

This type of research is qualitative descriptive to gather various information about phenomena that are in the field of research. This research was 351 students conducted at Elementary School (SDN Bojong I). This school was chosen as field of research because the schools run the counseling in accordance with the procedure counseling and character education curriculum that has been set. This can be seen in the implementation of daily learning activities by teachers who implement character education lesson and guidance and counseling teachers who nurture students in accordance with character education. The subjects of this study were the teacher of guidance and counseling, the principal and subject teachers. Data collection techniques performed by the authors in this study were the observation, survey, documentation and interview with the respondent.

\section{Instrument}

The research process was conducted using qualitative methods by placing the researcher as its main instrument comes with using observation sheet related to the dimensions of character education in physical education at school. [12] The use of qualitative methods to move from a phenomenological paradigm, which is a paradigm that seeks to understand the conditions and needs of the school physical education programs as part of the overall educational process. Through this qualitative methods, the research setting is not manipulated, but done in a situation where the phenomenon exists. In other words, the context in which human behavior and social phenomena under study should occur naturally. Conditions studied appropriately left in a state, a background circumstances who require the facts as a whole that can't be separated from its context.

TABLE I. VALUES STUDENTS VARIABLE

\begin{tabular}{|c|c|c|c|}
\hline \multicolumn{4}{|c|}{$\begin{array}{c}\text { Value Variable } \\
\text { (Misbach, 2006:18) }\end{array}$} \\
\hline Conceptual & Operational & Sub Variable & Indicator \\
\hline Anatomy & $\begin{array}{l}\text { Knowledge } \\
\text { (core value) }\end{array}$ & $\begin{array}{l}\text { Intellectual } \\
\text { Empathy }\end{array}$ & \multirow{4}{*}{$\begin{array}{l}\text { Honesty, Grace } \\
\text { Respect } \\
\text { discipline, } \\
\text { respect the rules }\end{array}$} \\
\hline Heteronomy & Discipline & Culture & \\
\hline Sosionomy & Community & Behavior & \\
\hline Autonomy & $\begin{array}{l}\text { Sociable } \\
\text { Environment }\end{array}$ & Self-control & \\
\hline
\end{tabular}

TABLE II. CHARACTER STUDENTS VARIABLE

\begin{tabular}{|c|c|c|c|}
\hline \multicolumn{4}{|c|}{$\begin{array}{l}\text { Character Variable } \\
\text { (Misbach, 2006:19) }\end{array}$} \\
\hline Conceptual & Operational & Sub Variable & Indicator \\
\hline Cognitive & Moral & $\begin{array}{l}\text { Rational } \\
\text { Knowledge }\end{array}$ & $\begin{array}{l}\text { Cooperation, } \\
\text { problem solving }\end{array}$ \\
\hline Affective & $\begin{array}{l}\text { Ethic } \\
\text { judgment }\end{array}$ & Ethic & \\
\hline Volition & commitment & $\begin{array}{l}\text { Good and bad } \\
\text { commitment }\end{array}$ & \\
\hline Behavior & $\begin{array}{l}\text { Knowledge of } \\
\text { the value }\end{array}$ & Habit & \\
\hline
\end{tabular}

III. RESEARCH FINDING AND DISCUSSION

The result of research indicating there are some characters that are owned by physical education (PE) that can form a positive character in children include :

First, PE tend to use or utilize the equipment or facilities in our environment without having to buy so need imagination and creativity.

Second, increase problem solving ability in children, stimulate the development of language and verbal skills, develop social skills, and a container of emotional expression.

Third, the games learning materials in physical education means foster social skills in children. Play allows children to interact with their social environment to teach children to recognize and respect other people.

Fourth, the games learning materials in physical education means to develop the capabilities and potential of children and can allow the child to recognize different kinds of objects, recognize its nature, as well as the events that occur in the environment. 
Fifth, the games learning materials in physical education view the noble values and moral messages such as shared values, honesty, responsibility, attitude gracefully (if you lose), and obey the rules.

The sport participation has been a major part of our life in the societies. Studies on sports participation have found that sports have both positive and negative influence on character buildings. [10]

The essential for learning character through sport players will respond by playing by the rules as long as values are consistently and relentlessly made central to how games are played. Character is not automatically built through sports. It can only be achieved through the efforts of parents, teachers, and coaches to demonstrate sportsmanship and other positive values. These examples of programs and strategies for teaching character put an emphasis on values. [11]

Based on the research results, it can be analyzed that the character building of students conducted by teacher through guidance and counseling services was relatively good. That is, the counseling teachers in cooperation with principals, subject teachers and other school staff have been working to establish and build the character of students in accordance with the applicable norms both within the school and in society.

\section{ACKNOWLEDGEMENT}

I would like to express my special thanks to my wife and children who helped me a lot in finalizing this project within the limited time frame.

\section{REFERENCE}

[1] Parker, M., \& Stiehl, J. Personal and social responsibility. In D. Tannenhill, \& J. Lund (Eds.). Standards based curriculum. Boston, M.A: Jones and Bartlett. 2004.

[2] Arizona Sports Summit Accord. Implementation strategies, Scottsdale, Arizona. CA: JICSE. Josephine Institute Center for Sports Ethics (24 May 1999).

[3] Barez, A. Sport as a school of life: The mental and physical characteristics, developmental objectives and coaching methods of youth sports. International Labour Organization Report. Geneva, Switzerland: ILO. 2008.

[4] Doty, J. Sports build character?! Journal of College \& Character. VII, 18. 2006.

[5] Prestwich, D.L. Character education in America's schools. School Community Journal, 14(1), 139- 150. 2004

[6] Hoge, J. Character education, citizenship education, and the social studies. Social Studies, 93(3), 103-108. 2002.

[7] Bohlin, K.D., Farmer, \& Ryan, K. Building character in schools resource guide. San Francisco, CA: Jossey-Bass. 2001.

[8] Backer-Fulghum, L. M., Patock-Peckham, J. A., King, K. M., Roufa, L., $\&$ Hagen, L. The stress response dampening hypothesis: How self-esteem and stress act as mechanisms between negative parental bonds and alcohol related problems in emerging adult.Addictive Behaviors Dec, 2001.

http://dx.doi.org/10.1016/j.addbeh.2011.12.012

[9] Drowatzky. Physical Education. New Jersey : Prentice-hall, Inc., Englewood cliffs, N.J. 1984.

[10] Omar - Fauzee, M.S., Nazarudin, Mohd Nizam., Saputra, Yudha M., Sutresna N., Taweesuk, Duangkrai., Chansem, Wipoj., Abd. Latif, Rozita., and Geok, Soh Kim. The Strategies for Character Building through Sports Participation. International Journal of Academic Research in Business and Social Sciences. March. 2012, Vol. 2, No. 3. pp. $48-58$.

[11] Lumpkin, A. Building character through sports. Strategies, 24(6), 2011. pp.13-15.

[12] Misbach, H.I. Peran Permainan Tradisional yang Bermuatan Edukatif dalam Menyumbang Pembentukan Karakter dan Identitas Bangsa. Jurusan Psikologi. Universitas Pendidikan Indonesia. 2009. 